\title{
Evaluation of DNA Damage in Peripheral Blood Lymphocytes Exposed to Gamma Radiation
}

\author{
Aya S Rady ${ }^{1, *}$, Soheir S. Korraa ${ }^{2}$, Wael M. Elshemey ${ }^{3,4}$, Amira Dakrory ${ }^{1}$ \\ ${ }^{1}$ Physics Department, Faculty of Women for Arts; Science and Education, Ain Shams University, Cairo, \\ Egypt. \\ ${ }^{2}$ Radiation Health Department, National Center for Radiation Research \& Technology, Cairo, Egypt. \\ ${ }^{3}$ Biophysics Department, Faculty of Science, Cairo University, 12613, Giza, Egypt. \\ ${ }^{4}$ Physics Department, Faculty of Science, Islamic University in Madinah, KSA.
}

\begin{abstract}
The contribution of Ionizing Radiation (IoR) in diagnosis and therapy increases every day. Therefore it is considered one of the most popular genotoxic exogenous agent. Hence the estimation of DNA damages due to the applied IoR dose is a must. There are many techniques used for the detection of DNA damage that depend on different measurable parameters. In this work, Comet and Cytochalasin-B Blocked Micronucleus (CBMN) assays were applied in order to detect the extent of DNA damage due to the exposure to different doses of gamma rays. Peripheral blood lymphocytes were exposed to doses of 2, 4, 6, and 8 Gy from ${ }^{137} \mathrm{Cs}$ gammaradiation source. Measured Comet assay dose parameters (tail DNA, tail length and tail moment) exhibit a significantly high correlation $(\mathrm{p}<0.01)$ with the exposure dose. However, micronuclei (MNi) (CBMN parameter) showed a p-value greater than 0.05. Thus we can conclude that Comet assay is evidently more reliable than CBMN in the estimation of the magnitude of DNA damage in peripheral blood lymphocytes due to exposure to gamma radiation.
\end{abstract}

Keywords: Comet assay, CBMN, Gamma radiation, DNA damages

\section{Introduction}

Since the beginning of the twentieth century, the contribution of IoR in the universal diagnostic and therapeutic tools accounts for the largest man-made contribution to the population dose [1]. The absorbed dose may contribute to DNA damage either directly or indirectly. It causes a variety of DNA damage including single- and double-strand breaks, DNA-protein cross-links, oxidized bases and basic sites of DNA. The weight of DNA damage varies according to the absorbed dose and cell type [2-5]. Hence the estimation of DNA damages due to the applied IoR dose is a critical issue. Different techniques were applied for

*Corresponding author: Aya S Rady, Physics Department, Faculty of Women for Arts; Science and Education, Ain Shams University.

E-mail: aya.rady@women.asu.edu.eg

Ayarady.biophys@yahoo.com 
detecting DNA damage using different measuring parameters corresponding to the induced biological effects [6]. In this study, two techniques were used for the estimation of the DNA damage in Lymphocyte cells irradiated with a range of doses of ${ }^{137} \mathrm{Cs}$ gamma-radiation $(2,4$, 6 and $8 \mathrm{~Gy})$.

The applied two techniques were comet and CBMN assays. Both were used as alternative methods with reported high sensitivity to the estimation of DNA damage, but were different in sample size and principle of measurement [7-10].

Single-Cell Gel Electrophoresis (SCGE) technique, known by comet assay, is usually described by simplicity, widespread sensitivity and high efficiency in analyzing small cell samples from any organ of eukaryotic organisms. In comet assay, the estimation of DNA damage can be performed at the individual cell level by identifying single- and double-strand DNA breaks, DNA-DNA/DNA-protein cross-links, oxidative base damage, alkali-labile sites, and open repair sites induced by a series of physical and chemical agents. Comet assay has been widely used in clinical and radiation biology for studying genetic toxicology and DNA repair [11-16].

The ability of charged loops/fragments of DNA migration under the application of electrical filed will contribute in the comet formation through an agarose gel. In this assay, the measured DNA damage depends essentially on the geometry of comet $[17, \mathbf{1 8}]$.

Comet assay procedure can be summarized in few steps as follows: firstly, cells are embedded in agarose on a microscope slide. Then, the embedded cells and nuclear membranes are subjected to lysing step using solution containing detergent and high salt. After that the DNA is subjected to electrical field at which alkaline electrophoresis step is done. Finally, it is the visualization step, cells are stained with an appropriate dye, and then the cellular DNA is visualized using a fluorescence microscope.

In this study, silver stain was used to visualize comets, so that the phase contrast microscope could be used in cell visualization. Breaks were quantified from geometric and image analysis of comet-shaped DNA with the help of commercially available software programs (casplab software). Numerous parameters can be measured, exploiting these programs together with tail length, \%Tail DNA, numerous measures of tail moment, etc [14, 19]. 
On the other hand, micronucleus scoring is the main principle in monitoring DNA damage using CBMN assay. Chromosome fragments or whole chromosomes are pulled out the nucleus at anaphase during nuclear division. At telophase, a nuclear envelope takes shape around these lagging chromosomes and fragments, which then compose the micronuclei. These micronuclei $(\mathrm{MNi})$ are usually smaller than the main nuclei in the cell nucleus. A convenient and reliable index of both chromosome breakage and chromosome loss are measured by MNi. Because MNi are expressed in cells that have completed nuclear division they are ideally scored in the binucleated (BN) stage of the cell cycle [20-22].

In the CBMN assay, cytochalasin-B (Cyt-B) is essential to perform the scoring of the investigated cells after completing one nuclear division at which cytokinesis performance is blocked by Cyt-B. Then, the scoring of MNi is performed within binucleated cells only, which enables reliable comparisons of chromosome damage between cell populations that may differ in their cell division kinetics [23- 25].

In this work, the comet and CBMN assays were applied in order to detect the extent of DNA damage in peripheral blood lymphocytes exposed to different doses of gamma rays. Thetwo techniques were applied to elucidate the most DNA damage measured parameter that showed high coincidence with the applied doses. The comet assay were supported by phase contrast to enhance the captured silver staining images and increase sensitivity of measured parameters. SPSS statistical software was applied on the measured comet and CBMN assays parameters. The SPSS software measured the correlation and 2-tailed significance between the measured parameters and the exposure doses.

\section{Materials and Methods}

\subsection{Sample preparation:}

Human peripheral blood lymphocytes were isolated from fresh blood obtained from healthy volunteers. The blood was drawn in EDTA-supplemented vacutainers to prevent blood from coagulation. The total blood samples were exposed to different doses of $\gamma$-radiation from the ${ }^{137} \mathrm{Cs}$ unit (dose rate $40 \mathrm{cGy} / \mathrm{min}$ ) at The National Center for Radiation Research and Technology, Egypt. These doses were 2, 4, 6, and 8 Gy which were listed as genotoxic doses to Lymphocytes in previous studies $[\mathbf{1 7}, \mathbf{2 6}, \mathbf{2 7}]$. The blood samples here were irradiated only and not mixed with any a radioactive material to them. Hence, the blood samples wastes were gathered and placed in acontainers with special color and mark. These containers were of a 
resistance and sealing material for infectious waste. Then, these were subjected to incineration under the authority of The National Center for Radiation Research and Technology, Egypt.

\subsection{Comet assay measurements:}

The comet assay was conducted under alkaline conditions with some modifications, as described by Nandhakumar et al. [28]. In brief, conventional microscope slides were first covered with a layer of $1 \%$ normal agarose. Then, a $50-\mu 1$ aliquot of the cell sample was mixed with $100 \mu \mathrm{l}$ of $0.5 \%$ low melting point agarose and added to the slides.

All slides were immersed in cooling lysing solution $(2.5 \mathrm{M} \mathrm{NaCl}, 100 \mathrm{mM}$ EDTA, $10 \mathrm{mM}$ Trisma base, $\mathrm{NaOH}$ was added to $\mathrm{pH} 10 ; 1 \%$ Triton X-100, 10\% DMSO were freshly added). The slides were kept in the lysing solution for a period up to 15 hours in refrigerator. Then the slides were placed in an electrophoresis tank and held in freshly prepared alkaline solution (10 N NaOH, 200 mM EDTA, pH > 13) for 20 minutes. The electrophoresis was then performed for 30 minutes at electrical voltage of 25 volt $(0.79$ volt $/ \mathrm{cm})$. The slides were then taken from the tank and washed three times in neutralizing buffer for 5 minutes ( $0.4 \mathrm{M}$ Tris, $\mathrm{pH}=7.5)$.

Afterwards, the slides were immersed in silver stain fixation solution (75 $\mathrm{g}$ of trichloroacetic acid, $25 \mathrm{~g}$ zinc sulphate and $20 \mathrm{ml}$ of glycerol dissolved in 500ml of distilled $\mathrm{H}_{2} \mathrm{O}$ ) for $10 \mathrm{~min}$ and the slides were left to dry overnight. The DNA was stained with silver staining solution. Finally, the slides were immersed in silver staining stopping solution $(1 \% \mathrm{v} / \mathrm{v}$ glacial acetic acid) for $10 \mathrm{~min}$. At this point, the slides were ready for visualization under phase contrast microscope (Euromax iScope) and comet images were captured using CCD camera and analyzed using casplab Software. All results were evaluated in terms of six image analysis parameters: tail moment, tail length, comet length, tail DNA \%, Olive Tail Moment (OTM) and tail DNA (tail intensity). Most of these parameters are represented in figure 1. 


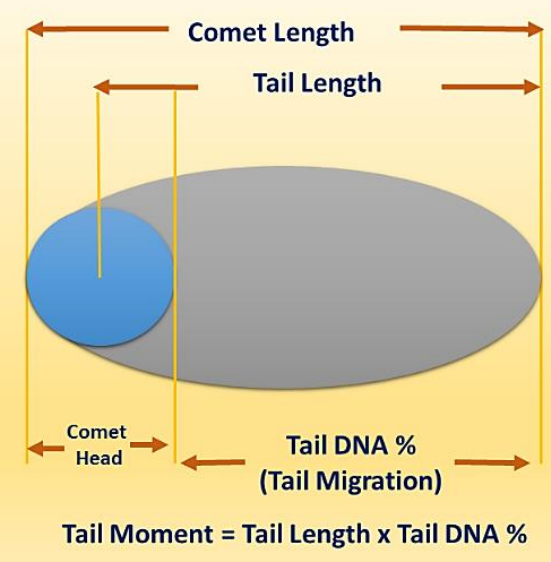

Fig 1. Comet assay measurements parameters

\subsection{CBMN assay measurements:}

The CBMN assay was performed with some modifications, as described by Fenech [22]. Whole blood culture was applied here to perform CBMN assay. Typically, a volume of whole blood $0.5 \mathrm{ml}$ was added to $4.5 \mathrm{ml}$ of culture medium RPMI 1640 medium containing $20 \%$ heat inactivated Foetal calf serum. Cells were then stimulated to divide by adding phytohemagglutinin (PHA) to each culture tube at $10 \mu \mathrm{l} / \mathrm{ml}$ (from a stock solution in $\mathrm{H}_{2} \mathrm{O}$ of $2.25 \mathrm{mg} / \mathrm{ml}$ ) and incubated at $37^{\circ} \mathrm{C}$ and humidified atmosphere containing $5 \% \mathrm{CO}_{2}$. After 44 hours of PHA stimulation, the recommended optimal concentration of Cyt-B for accumulating BN cells in whole blood cultures was found to be $6 \mu \mathrm{g} / \mathrm{ml}$. Culture tubes were then reincubated. After 28 hours from the addition of Cyt-B, the BN lymphocytes were harvested by centrifugation and the supernatant medium was removed.

Cells were re-suspended in $7 \mathrm{ml}$ of cold hypotonic solution $(0.56 \mathrm{gm}$ of $\mathrm{KCl}$ in 100 $\mathrm{dH}_{2} \mathrm{O}$ ) for 30 min causing rapture to red blood cells. After removing the hypotonic solution, cells were fixed using $5 \mathrm{ml}$ fixative consisting of methanol: Glacial acetic acid (3:1).

The cells were re-suspended gently and the suspension is dropped onto clean glass slides and allowed to dry. Finally, cells were subjected to Giemsa staining and MN were scored in $1000 \mathrm{BN}$. 


\section{Results and Discussion:}

The comet assay slides were prepared using sliver staining and some of capture images are shown in figure 2 . The comets appear slightly different at different doses of IoR and have acceptable resolution.
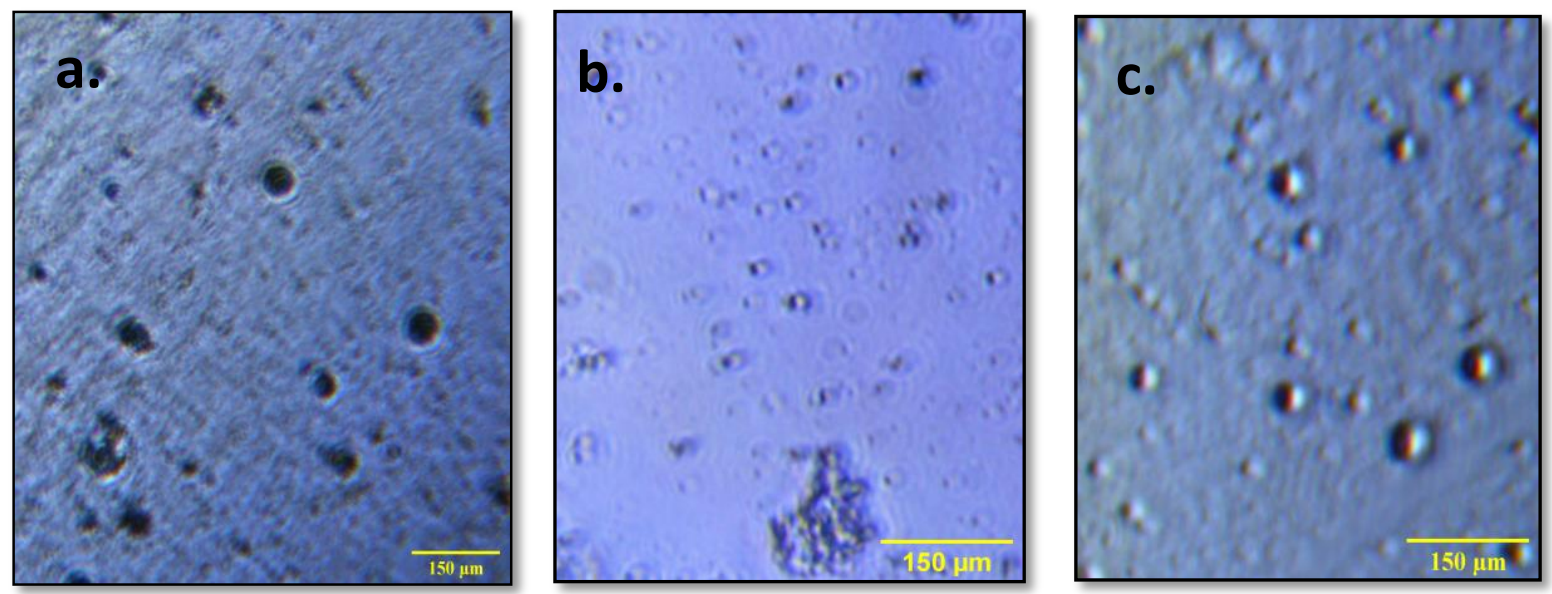

Fig 2. Silver stained comet assay at different exposure doses of ionizing radiation a. control (no tail appears), b. at $2 \mathrm{~Gy}$ and c. at $8 \mathrm{~Gy}$. Images were capture at magnification of $400 \mathrm{x}$.

Casplab software was used to analyze the captured images. DNA liberated fragments were measured in the six different comet assay parameters. The parameters were tail DNA (tail intensity), tail DNA \%, tail length, comet length, tail moment and Olive Tail Moment (OTM). As shown in figure 1.3., the comet assay parameters appear to exhibit a response that is in coincidence with the value of exposure dose. The increase in IoR dose is associated with an increase in NA liberated fragments (DNA damage). For all parameters, one can notice a highly linear dose-response characteristics, with $\mathrm{R}^{2}$ value greater than 0.9 , except for the OTM parameter $\left(\mathrm{R}^{2}=0.8\right)$, Figure $3(\mathrm{a}-\mathrm{f})$. This result is in coincidence with previous publications. Sudprasert et al. studied the effect of low dose (0, 5, 10, 20 and 50) cGy on whole blood and peripheral lymphocytes. Their study revealed a dose-dependent effect of gamma radiation on DNA damage. Their results suggested that the genotoxic effects of gamma radiation may be due to a combination of DNA-damaging effects and reduced DNA repair capacity [29]. In similar study, Shetty et al. evaluated the extent of DNA damage induced by $\gamma$-irradiation using alkaline comet assay, but their study was applied on Aedes Aegypti. Adult male A. aegypti were exposed to seven different doses of gamma radiation, ranging from $1 \mathrm{~Gy}$ to $50 \mathrm{~Gy}$. DNA damage was measured as the percentage of comet tail DNA. Their results revealed a significant 
linear increase in DNA damage in proportional to the dose of gamma radiation the organism received, except in those treated with $1 \mathrm{~Gy}$. Also, they noticed that a reduction in the highest amount of DNA damage with postirradiation time. They regarded this notable reduction into two possible postulates which were repair of the damaged DNA and/ or loss of heavily damaged cells as the postirradiation time increased [30] .

Also alkaline comet assay were carried out on Blood samples which were obtained from fifty medical people occupationally exposed to ionizing radiation and fifty corresponding unexposed healthy controls. These samples had been subjected to alkaline Comet assay as a biomarker to evaluate the continued exposure to ionizing radiation. The comet assay were measured in tail length and tail moment as the global parameters. They found highly significant correlation between the measured parameters and the job of exposed person, for example the tail lengths were greater in technicians than nurses and physicians[31].

Prasad et al. showed an increase in DNA liberated fragments from human blood lymphocytes as a result of $\gamma$-irradiation exposure at doses of 1, 2, 4 Gy. In their study, the induction of DNA fragments was directly proportional to applied dose. They attributed the increase in DNA liberated fragments to the association between oxidative damage in cultured human blood lymphocytes and $\gamma$-irradiation exposure [32].

Comet assay calibration curves were reviewed by Collins et al., these curves obtained in different laboratories using ionizing radiation ( $\gamma$-radiation and X-rays) to induce DNA breaks in lymphocytes and hela cells. The curves revealed gradual increase in DNA breaks in response to the increase in IoR dose. The concerned Comet assay parameters were tail DNA\% and tail moment [18]. 

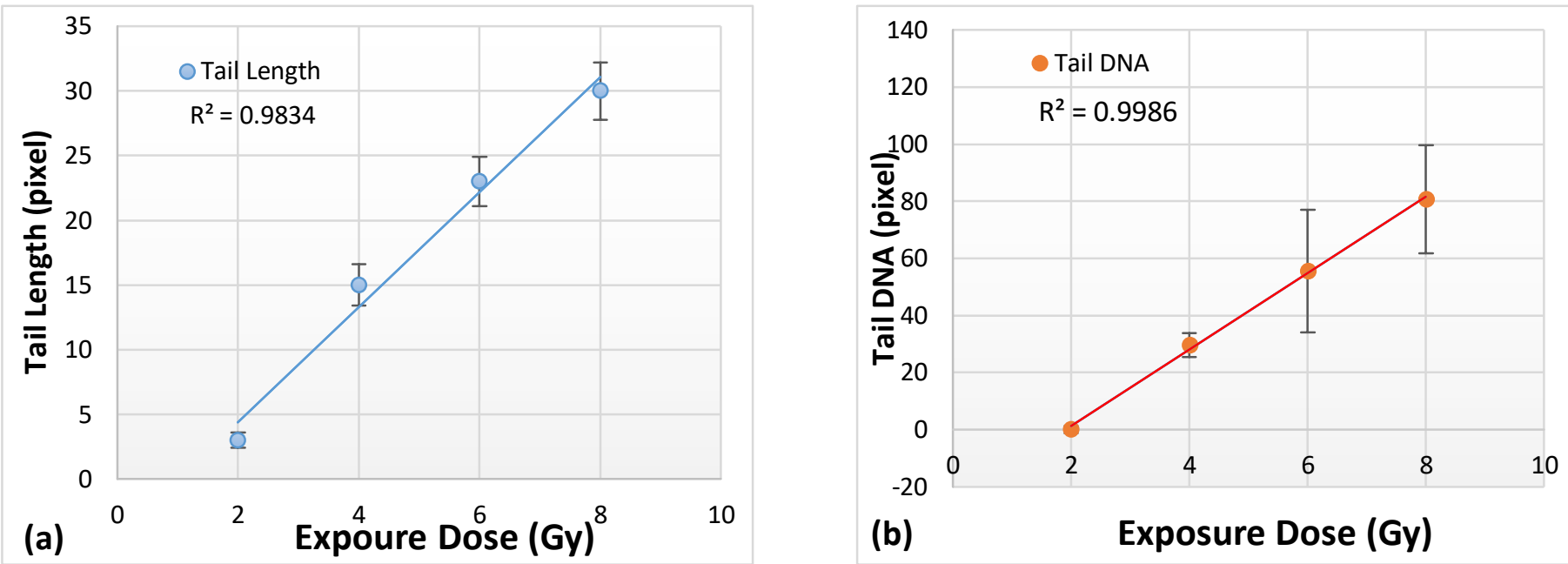

Expoure Dose (Gy) ${ }^{8}$

(b)

Exposure Dose (Gy)
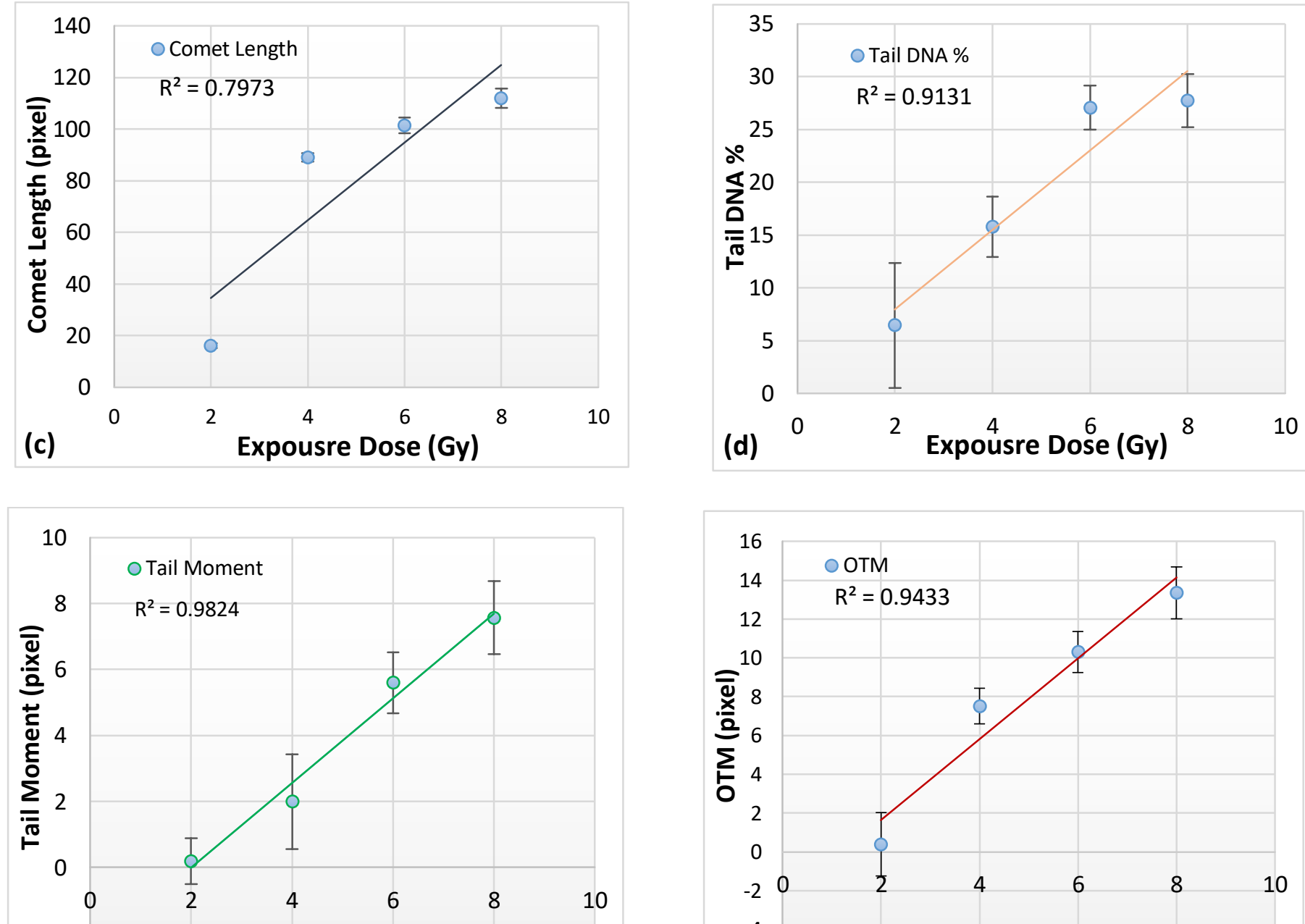

(e) Expousre Dose (Gy)

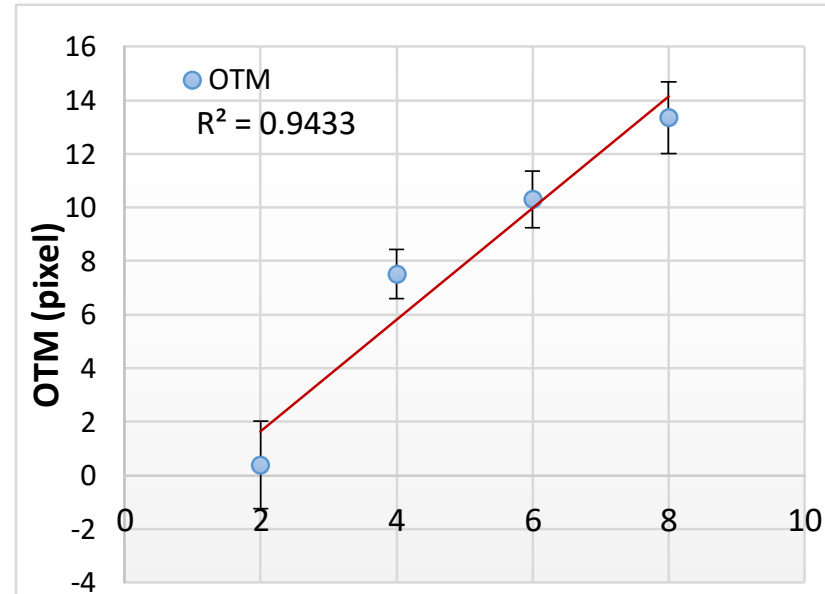

(f)
Expoure Dose (Gy)

Fig 3. Dose response curves at different comet assay parameters. (a) Tail length, (b) Tail DNA, (c) Comet length, (d) Tail DNA\%, (e) Tail moment, (f) OTM. Comet length, tail length and tail DNA were measured in pixels (1 pixel $=264.5833 \mu \mathrm{m}$ ) 
For comparison with comet assay, CBMN was applied on the same samples. The frequency of micronuclei (MNi) was assayed per 1000 binucleated cells. Figure 4 shows the binucleated cells with and without the micronuclei. Change in MNi frequency is the indicator of DNA damage in CBMN assay. As shown in comet assay results, a high correlation between $\mathrm{MNi}$ and exposure dose were found $\left(\mathrm{R}^{2}=0.919\right)$ also.
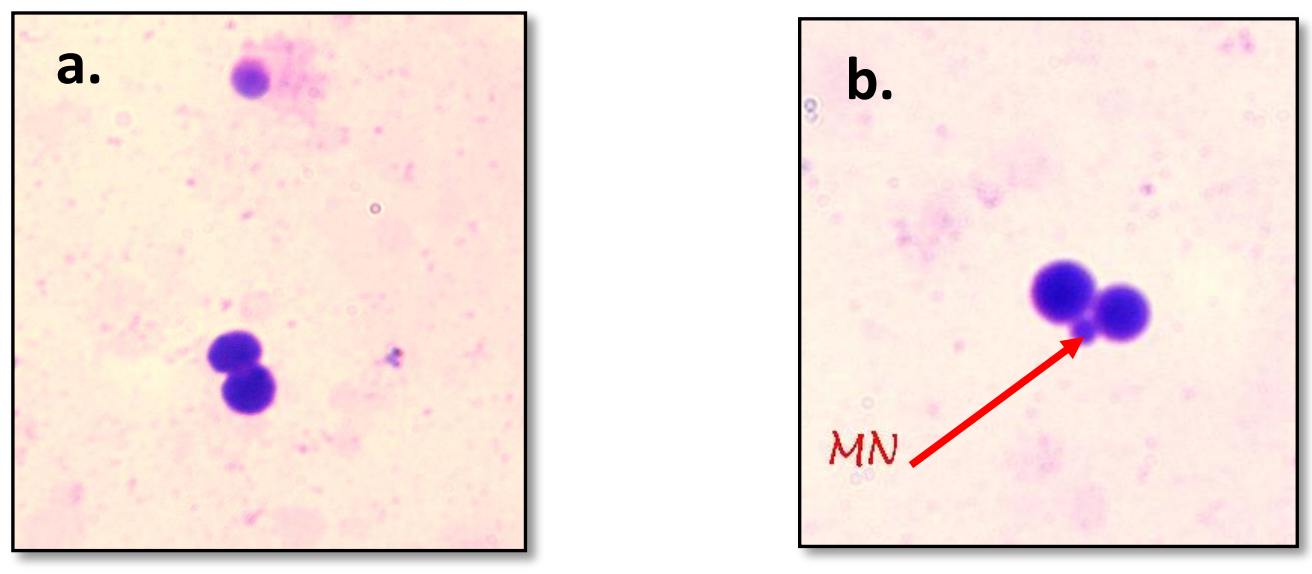

Fig 4. a. binucleated lymphocytes cell b. binucleated lymphocytes cell with micronuclei . Images were capture at magnification of $1000 x$

In this work, it can be observed that at different gamma irradiation doses, almost all comet assay parameters are significantly highly correlated. Unfortunately, this is not the case for $\mathrm{MNi}$ (CBMN parameter) as can be seen in Table 1. Tail DNA, Tail Length and Tail Moment parameters show the highest significant correlation to the applied dose $(\mathrm{p}<0.01)$. Nevertheless, Both MNi and comet length have p-value greater than 0.05 .

Table 1. Pearson correlation and significance (2-Tailed) for measured comet assay and CBMN assay parameters.

\begin{tabular}{ccc} 
Measured Parameter & Pearson Correlation & Sig. (2-Tailed) \\
MNI & .919 & .081 \\
TAIL DNA & $.999^{* *}$ & $.001^{* *}$ \\
\hline TAIL DNA \% & $.956^{*}$ & $.044^{*}$ \\
\hline TAIL LENGTH & $.992^{* *}$ & $.008^{* *}$ \\
\hline COMET LENGTH & .893 & .107 \\
\hline TAIL MOMENT & $.991^{* *}$ & $.009^{* *}$ \\
\hline OLIVE TAIL MOMENT & $.971^{*}$ & $.029 *$ \\
\hline (OTM) & & \\
\hline
\end{tabular}


**, * is given if the correlation was significant at a chosen alpha level

**. Correlation is significant at the 0.01 level (2-tailed), *. Correlation is significant at the 0.05 level (2-tailed).

The comet assay slides were prepared in sliver staining and visualized using phase contrast microscope. The use of phase contrast might contribute in the enchantment of comet image and the increase in the efficiency of comet assay parameters. The silver stain was preferred here instead of propidium iodide or ethidium bromide stain (fluorescent DNA stains). Despite, the comets are usually visualized in these stains, they have some of disadvantages. The potential carcinogenic, the requirement of specific equipment (e.g., a high-quality fluorescence microscope), immediately analyzed of the slides were included in these disadvantages [33]. On the other hand, silver staining comets may yield less contrast than its florescent ones.

\section{Conclusion:}

The study emphasized on the high sensitivity of comet assay and CBMN assay in determination of DNA damage. But, Comet assay is more convenient in measuring of DNA damages evolved in lymphocytes cells irradiated with gamma radiation. Tail DNA, tail Length and tail Moment parameters are still the more significant parameters in comet assay as in previous publications.

\section{References:}

[1] S. Angelini, R. Kumar, F. Carbone, F. Maffei, C. G. Forti, F. S. Violante, V. Lodi, S. Curti, K. Hemminki, P. Hrelia , "Micronuclei in humans induced by exposure to low level of ionizing radiation: Influence of polymorphisms in DNA repair genes," Mutat. Res. - Fundam. Mol. Mech. Mutagen. 570 : (2005) 105-117.

[2] D. R. Spitz, E. I. Azzam, J. J. Li, and D. Gius, "Metabolic oxidation / reduction reactions and cellular responses to ionizing radiation: A unifying concept in stress response biology," Cancer Metastasis Rev. 23: (2004)311-322.

[3] B. Murat, O. Gokhan, and E. Cuneyt, Basic Radiation Oncology, Springer,(2010), London.

[4] E. I. Azzam, J. P. Jay-Gerin, and D. Pain, "Ionizing radiation-induced metabolic oxidative stress and prolonged cell injury," Cancer Lett. 327: (2012) 48-60.

[5] L. Al-jameel, R. S. Ahmed, and H. A. Shamran, "Ionizing Radiation Effect and DNA damage in the workers of Al-Tuwaitha Nuclear Site," Iraqi J. Sci. 60 : (2019) 2636-2641.

[6] S. Kaur, K. K. Galhna, and N. Gautam, "Assessment of Radiation Induced DNA Damage in Human Peripheral Blood Lymphocytes Using COMET Assay," Int. J. Life. Sci. Sci. Res. 3: 
(2017) 1208-1214.

[7] R. P. Araldia, T. C. Meload, T. B. Mendes, P. Luizde Sá Júniora, B. H. N. Nozimad, E. T. Ito, R. Franco de Carvalho , E. Barreiros de Souza, R. Stoccoa, "Using the comet and micronucleus assays for genotoxicity studies : A review," Biomed. Pharmacother. 72: (2015) 74-82.

[8] J. de Lapuente, J. Lourenço, S. A. Mendo, M. Borràs, M. G. Martins, P. M. Costa, M. Pacheco, "The Comet Assay and its applications in the field of ecotoxicology: a mature tool that continues to expand its perspectives," Front. Genet. 6: (2015), doi: 10.3389/fgene.2015.00180.

[9] G. Gajski, M. Geri, V. Oreščaninb, and V. Garaj-Vrhovac, "Ecotoxicology and Environmental Safety Cytokinesis-block micronucleus cytome assay parameters in peripheral blood lymphocytes of the general population: Contribution of age, sex, seasonal variations and lifestyle factors," Ecotoxicol. Environ. Saf. 148: (2018) 561-570.

[10] S. Sommer, I. Buraczewska, and M. Kruszewski, "Micronucleus Assay: The State of Art , and Future Directions," 21: (2020), doi:10.3390/ijms21041534.

[11] N. P. Singh, M. T. McCoy, R. R. Tice, and E. L. Schneider, "A simple technique for quantitation of low levels of DNA damage in individual cells," Exp. Cell Res. 175: (1988) 184-191.

[12] R. R. Tice, E. Agurell, D. Anderson, B. Burlinson, A. Hartmann , H. Kobayashi, Y. Miyamae , E. Rojas, J.C. Ryu , Y. F. Sasaki , "Single Cell Gel / Comet Assay : Guidelines for In Vitro and In Vivo Genetic Toxicology Testing," Environmental and Molecular Mutagenesis 35: (2000) 206-221.

[13] A. R. Collins and A. Azqueta, "DNA repair as a biomarker in human biomonitoring studies ; further applications of the comet assay," Mutat. Res. - Fundam. Mol. Mech. Mutagen. 736 : (2012) 122-129.

[14] Z. Kayaalti, S. Yalcin, and T. Soylemezoglu, "Searching of Standard Comet Assay Parameters for Detecting Lymphocyte Council for Innovative Research," Journal Of Advances in Biology 3: (2014) 234-241.

[15] M. Khisroon, A. Khan, M. Naseem, and N. Ali, "Evaluation of DNA damage in lymphocytes of radiology personnel by comet assay," J. Occup. Health, 57: (2015) 268-274.

[16] M. Augustyniak, M. Gladysz, and M. Dziewie, "Mutation Research / Reviews in Mutation Research The Comet assay in insects - Status , prospects and benefits for science," Mutat. Res., vol. 767, pp. 67-76, 2016.

[17] T. S. Kumaravel and A. N. Jha, "Reliable Comet assay measurements for detecting DNA damage induced by ionising radiation and chemicals," Mutation Research 605 : (2006) 7-16.

[18] A. R. Collins, A. AA. Oscoz, G. Brunborg, I. Gaivão, L. Giovannelli, M. Kruszewski , C. C. Smith, R. Stetina , "The comet assay: Topical issues," Mutagenesis 23: (2008) 143-151.

[19] P. Duez, G. Dehon, A. Kumps, and J. Dubois, "Statistics of the Comet assay: a key to discriminate between genotoxic effects ," Mutagenesis 18: (2003) 159-166. 
[20] J. A. Heddle, M. C. Cimino, M. Hayashi, F. Romagna, M. D. Shelby, J. D. Tucker, P. Vanparys , J. T. MacGregor., "Micronuclei as an Index of Cytogenetic Damage : Past, Present , and Future," Environmental and Molecular Mutagenesis 291 : (1991) 277-291.

[21] M. Fenech, "The in vitro micronucleus technique," Funtamental and Molecular Mechanisms of Mutagenesis 455: (2000) 81-95.

[22] M. Fenech, “Cytokinesis-block micronucleus cytome assay,” Nat. Protoc. 2: (2016) 10841105 .

[23] Y. Shibamoto, C. Streffer, C. Fuhrmann, and V. Budach, "Tumor Radiosensitivity Prediction by the Cytokinesis-Block Micronucleus Assay," Rad. Research 128 : (1991) 293300 .

[24] P. Thomas and M. Fenech 2010 in V. V. Didenko DNA Damage Detection In Situ, Ex Vivo, and In Vivo Methods and Protocol ( Springer) p 218.

[25] A. T. Doherty 2012 in J. M. Parry and E. M. Parry Genetic Toxicology Principles and Methods (Humana Press) p 121.

[26] M. Inoue, G.-P. Shen, M. A. Chaudhry, H. Galick, J. O. Blaisdell, and S. S. Wallace, "Expression of the Oxidative Base Excision Repair Enzymes is not Induced in TK6 Human Lymphoblastoid Cells after Low Doses of Ionizing Radiation,” Radiat. Res., vol. 161: (2004) 409-417.

[27] D. C. Kim, M. Kang, A. Biswas, C. R. Yang, X. Wang, and J. X. Gao, "Effects of low dose ionizing radiation on DNA damage-caused pathways by reverse-phase protein array and Bayesian networks," J. Bioinform. Comput. Biol. 15: (2017) 1-18.

[28] S. Nandhakumar, S. Parasuraman, M. M. Shanmugam, R. R. K, P. Chand, and V. B. B, "Evaluation of DNA damage using single-cell gel electrophoresis ( Comet Assay )," vol. 2, no. 2, 2011.

[29] W. Sudprasert, P. Navasumrit, and M. Ruchirawat, "Effects of low-dose gamma radiation on DNA damage, chromosomal aberration and expression of repair genes in human blood cells,” Int. J. Hyg. Environ. Health 209 : (2006) 503-511.

[30] V. Shetty, N. Shetty, S. Ananthanarayana, S. Jha3, and R. Chaubey4, "Evaluation of gamma radiation-induced DNA damage in Aedes aegypti using the comet assay," Toxicol. Ind. Health: (2017)1-8.

[31] V. Garaj-vrhovac and N. Kopjar, "The alkaline Comet assay as biomarker in assessment of DNA damage in medical personnel occupationally exposed to ionizing radiation," Mutagenesis $18:$ (2003) 265-271.

[32] N. R. Prasad, V. P. Menon, V. Vasudev, and K. V Pugalendi, "Radioprotective effect of sesamol on $\gamma$-radiation induced induced DNA damage, lipid peroxidation and antioxidants levels in cultured human lymphocytes," Toxicology 209: (2005) 225-235.

[33] S. B. Nadin, L. M. V. Roig, and D. R. Ciocca, “A Silver Staining Method for Single-cell Gel Assay,” J. Histochem. Cytochem., 49: (2001) 1183-1186. 


\section{الملخص العربي}

تقدير الاضرار اللاحقة بالحامض النووي لكرات الدم البيضاء نتيجة التعرض لاشعاع جاما

آيه سيد حسن راضي 1 ـ- سهير سعد قراعة 2 - وائل محي الدين الثيمي 3، 4ــميرة دكروري1

1- قسم الفيزياء - كلية البنات للأداب و العلوم و التربية - جامعة عين شمس - القاهرة - جمهورية مصر العربية.

2- قسم البحوث الصحية ـ المركز القومي لبحوث وتكنولوجيا الاشعاع ـ هيئة الطاقة الذرية بمدينة نصر ـالقاهرة -

$$
\text { جمهورية مصر العربية. }
$$

3- ق قسم الفيزياء الحيوية - كلية العلوم -جامعة القاهرة ص ب 12613 الجيزة - جمهورية مصر العربية. 4- قسم الفيزياء ـ كلية العلوم ـ الجامعة الاسلامية ـ المدينة المنورة ـ المملكة العربية السعودية.

يوجد العديد من التقنيات المستخدمة في تقدير نسبة الأضرار اللاحقة بالحامض النووي والتي تختلف في أساليب

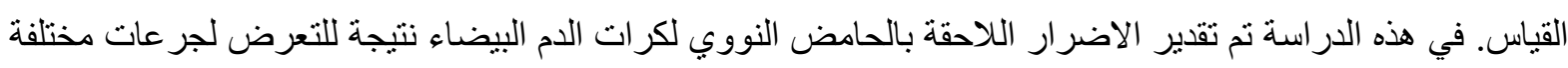
من إثعاع جاما و ذلك باستخدام تقنيتين مختلفتين و هما: اختبار المذنب و اختبار النواة الصغيرة المعدل باستخدام مادة (Cytochalasin-B Blocked) لكر ات الدم البيضاء مقارنة بمثيله المستخدم في الدراسة. 